\title{
Farmers Use of Erosion Control Measures in Anambra State Nigeria
}

https://dx.doi.org/10.4314/jae.v22i3.17

\section{Nwobodo Cynthia E.}

Department of Agricultural Extension,

University of Nigeria, Nsukka. Enugu State, Nigeria

Email: cynthia.nwobodo@unn.edu.ng

Phone no: 08039462574.

\section{Otunwa Samuel}

Department of Agricultural Extension,

University of Nigeria, Nsukka. Enugu State, Nigeria

Email:otuwa.samuel185890@unn.edu.ng

Phone: 07068190410

\section{Ohagwu Violet A.}

Department of Agricultural Extension,

University of Nigeria, Nsukka. Enugu State, Nigeria

Email: violet.ohagwu@unn.edu.ng

Phone no: 08134960506

\section{Enibe David Okechukwu}

Department of Agricultural Economics and Extension

Chukwuemeka Odumegwu Ojukwu University, Igbariam Campus, Anambra State, Nigeria

Email: enibedav@yahoo.com

Phone: 08137829887

\begin{abstract}
The study investigated the attitude of farmers to the use of erosion control measure in Anambra State, Nigeria. Multistage sampling technique was used to select 120 farmers used for the study. Results show that majority (99.2\%\&98.3\%) of the respondents indicated that rain water run-off and poor road construction respectively were the major causes of soil erosion in the area. All (100\%) the respondents used mixed cropping, tie ridging and mulching as control practice against erosion. Challenges to farmers' use of erosion control practices were: unavailability of resource required ( $\bar{x}=3.44)$, and high cost of using the practice $(\bar{x}=3.23)$. Respondents had positive attitude to erosion control as indicated by the results including: it is good to adopt some erosion practices as it helps to save the soil $(\bar{x}=2.68)$, interested in issues concerning erosion as this will help me gain knowledge of how to control it $(\bar{x}=2.68)$, I always teach their family members how to control erosion on their farmland/homes ( $\bar{x}=2.56)$, I will like to be trained about erosion control even though it has not directly affected them $(\bar{x}=2.55)$.in the area.
\end{abstract}


Creative commons User License: CC BY-NC-ND

Abstracted by: EBSCOhost, Electronic Journals Service (EJS), Google Scholar, Journal Seek, Scientific Commons,

Food and Agricultural Organization (FAO), CABI and Scopus
Journal of Agricultural Extension

Vol. 22 (3) October, 2018

ISSN(e): 24086851; ISSN(Print); 1119944X

http://journal.aesonnigeria.org

http://www.aiol.info/index.phpliae

Email: editorinchief@aesonnigeria.org

The paper advocates that government at all levels should provide financial incentives to farmers so that they can afford some good erosion control practices which are costly for them.

\section{Keywords: environmental degradation, farmers' attitude, erosion control practices.}

\section{Introduction}

Soil erosion is a well-known environmental problem in south eastern Nigeria. It has attracted the interest of professionals (geographers, cartographers, geomorphologists, chemists and engineers, etc.) who are interested in its studies (causes and effects) and has been of great concern to affected communities who are interested in its solution (control and minimization). Soil erosion has been identified as a serious environment problem with a multiplicity of social and economic consequences. It is a disastrous form of environmental degradation whose effects is multi- dimensional. According to Pidiwirmy (2010), previous erosion on a particular has an effect on the erodibility of that soil for a number of reasons: many exposed subsurface soils on eroded site tend to be more erodible than the original soil, because of their poorer structure and lower organic matter. The lower nutrient levels often associated with subsoil contribute to lower crop yield and generally poorer crop cover which in turn provides less crop protection for the soil. The implications of soil erosion extend beyond the removal of valuable topsoil, crop emergence, growth and yield are directly affected through the loss of natural nutrient and applied fertilizers with the soil. Sediment can be deposited on down slope properties and can contribute to road damage (Pidiwirmy, 2010).

Land is one of the basic resources in agricultural production in which the availability help increases farmers productivity (Babalola and Olayemi, 2013; Raufu and Adetunji, 2012). Agricultural intensification is a type of strategy for rural livelihood which helps farmers to increase in their agricultural production per unit of input for sustainability (Yang, Liu, Lun, Min, Zhang, and Li., 2018). According to Dessie, (2013) sustainable livelihood approach can be defined in terms of the ability of an individual to enhance its assets and capabilities in the face of shocks and stresses over time. Poufoun (2016) argue that livelihood strategies in rural areas of developing world have key choices to determining natural resource management. The most pressing challenge of Nigerian agriculture in the new millennium is how it can meet the food need of an ever-bourgeoning population in the face of the myriads of social, cultural and economic problems that negates sustainable land management (Saheed and Isa, 2017). This Sustainable land management practices (SLMP) is the adoption of land use systems that, through appropriate management practices, enables land users to maximize the economic and social benefits from the land while maintaining or enhancing the ecological support functions of the land resources (Food and Agricultural Organization (FAO), 2016). Sustainable intensification of agriculture is very important in achieving global food security (United Nations, 2014: Onyeneke, 2016). However, Sustainable development in agriculture in Nigeria has been threatened by environmental degradation arising from soil erosion menace (Onu, 2013). 
Creative commons User License: CC BY-NC-ND

Abstracted by: EBSCOhost, Electronic Journals Service (EJS), Google Scholar, Journal Seek, Scientific Commons,

Food and Agricultural Organization (FAO), CABI and Scopus
Journal of Agricultural Extension

Vol. 22 (3) October, 2018

ISSN(e): 24086851; ISSN(Print); 1119944X

http://journal.aesonnigeria.org

http://www.aiol.info/index.phpliae

Email: editorinchief@aesonnigeria.org

In Anambra State, almost all the communities are affected by one form of erosion or the other. There are up to 500 gully erosion sites spread across all the rural communities in the State (Obi and Okekeogbu, 2017: Ume et. al., 2014). This condition has affected the livelihood of farmers in a variety of ways including loss of arable lands, loss of residential homes, and loss of income (Okorafor, Akinbile and Adeyemo, 2017). The economic cost of erosion is very difficult to quantify, but it is definitely very large, huge sums of money are spent each year repairing damage caused by erosion or reinforcing existing structures and land against erosion. Akinbile, Aminu and Kolade (2018) assert that disasters affect livelihood of rural people through its effects on their lives and subsistence. Erosion control measures such as terracing requires high labour and investment costs for smallholders (Chapagain and Manish, 2017). Farmers can use simple methods of erosion control which are less expensive and less laborious to establish and maintain. For instance, cover crops can improve the soil structure thereby decreasing the erodibility of the soil. Other simple erosion control measures include: strip cropping and mulching (Okorafor, Akinbile and Adeyemo, 2017). Despite the awareness of these traditional techniques and management actions of the local farmers to control erosion and protect the environment, they have remained largely under studied, unexplored and neglected.

This study therefore aims at addressing these missing links in Anambra State. To transfer knowledge, skills and management to farmers, it is necessary to generate desirable changes in the attitudes of farmers as first step; therefore, assessing attitudes in connection with the principles and concepts of sustainable agriculture gives a standard of existing status on which basis planning could be made to achieve desirable status (Saleh et.al, 2016).

\section{Purpose of the study}

The broad objective of this study was to ascertain the attitude of farmers to use of erosion control measures in Anambra state. The specific objectives were to:

1. ascertain the perceived causes of erosion in the area,

2. identify erosion control practices used by farmers;

3. ascertain attitude of farmers to erosion control; and

4. ascertain challenges to farmers' use of erosion control practices.

Multistage sampling procedure was employed in selecting respondents for the study. Two out of the five Agricultural Development Programme (ADP) zones namely, Awka and Aguata were purposively selected based on prominence in agricultural activities as well as proneness to soil erosion. Two (2) blocks were selected purposively from each of the two (2) zones based on presence of erosion sites. Thus, Aniocha and Njikoka were selected from Awka, while Orumba North and Orumba South were selected from Aguata zone. From each of the blocks selected, three (3) circles were randomly selected giving a total of 12 circles. Then 10 farmers were randomly selected from each circle giving a total of 120 respondents used for the study. Questionnaire was used in collecting information from the respondents. To obtain information on socio-economic characteristics, respondents were asked to indicate their sex as male or female, age (in years), marital status (single, married, divorced/separated, or widowed), educational level (no formal education, primary 
Creative commons User License: CC BY-NC-ND

Abstracted by: EBSCOhost, Electronic Journals Service (EJS), Google Scholar, Journal Seek, Scientific Commons,

Food and Agricultural Organization (FAO), CABI and Scopus
Journal of Agricultural Extension

Vol. 22 (3) October, 2018

ISSN(e): 24086851; ISSN(Print); 1119944X

http://journal.aesonnigeria.org

http://www.aiol.info/index.phpliae

Email: editorinchief@aesonnigeria.org

school attempted, primary school completed, secondary school attempted, secondary school completed, tertiary education), household size, annual household income (in naira), and their membership of social organization. In order to ascertain farm characteristics, respondents were asked to indicate their farm size (hectares), type of farming enterprise, source of farm land, sloppiness of farm land, gravity of soil erosion on farm land.

To elicit information for objective two, respondents were asked to indicate the erosion control measure they practiced by ticking yes or no to a list of erosion control measure, They were also asked to specify others as it applied to them. Data on attitude of farmers to erosion control (objective 3) was collected by asking respondents to rate a list of positive and negative attitude questions on a four-point Likert-type scale of strongly agree $=4$, agree $=3$, disagree $=2$, and strongly disagree $=1$ with a mean of 2.5. For positive statements, any response that is greater than or equal to 2.5 will be regarded as right attitude while responses that are less than or equal to 2.5 will be regarded as right attitude for negative statement. In order to ascertain challenges to the use of erosion control, respondents were asked to tick yes $=1$ or no $=2$ to indicate the challenges they encountered in erosion control in the area. Respondents were asked to rate the challenges they faced in erosion control in a four part Likert-type scale of to a great extent (4), moderate extent (3), little extent (2), and no extent (1) with a mean of 2.5.

\section{Result and Discussion}

\section{Socio- economic Characteristics of Respondents}

Table 1 shows that the majority $(62.5 \%)$ of the respondents were male. Greater proportions (20\%) were aged 41-50 years. The mean age of the respondent was 48.2 years. This implies that the majority of the respondents was still in their active productive age and thus have high propensity to acquire new knowledge that will aid to boost their practice of erosion control. More advanced farmers adopt less technology as compared to young farmers. This is as a result of the fact that as farmers grow older, there is an increase in risk aversion and decreased interest in long term investment in farm (Udimal, Jincai, Mensah, and Caesar, 2017).

The majority $(75.8 \%)$ of the respondents were married, the mean household size was about 6 persons. Marital status and household size are related socio-economic variables which could serve as driving forces towards participation in soil erosion activities needed to meet household agricultural production needs. The larger the household size, the more likely the farm labour will be available to enhance their farming activities and the practice of erosion control. Greater proportion (26.7\%) of the respondent completed their secondary school education. This finding indicates appreciable level of education among the respondents. Nwaobiala (2018) noted that education enhances adoption of agricultural innovation. Thus the higher the educational attainment among farmers, the more favourable their disposition is towards group cohesion and participation in modern soil erosion activities for sustainable agricultural production. Entries in Table 1 indicate that greater proportion $(40.8 \%)$ of the respondents had farming as their major occupation. The mean monthly household income of the respondents was $28,406.78$. This implies that the 
Creative commons User License: CC BY-NC-ND

Abstracted by: EBSCOhost, Electronic Journals Service (EJS),

Google Scholar, Journal Seek, Scientific Commons,

Food and Agricultural Organization (FAO), CABI and Scopus
Journal of Agricultural Extension

Vol. 22 (3) October, 2018

ISSN(e): 24086851; ISSN(Print); 1119944X

http://journal.aesonnigeria.org

http://www.ajol.info/index.php/iae

Email: editorinchief@aesonnigeria.org

respondent were low income earners and relying on personal savings could constrain the use of effective erosion control measure by farmers.

Table1: Socio-economic characteristics of respondents

\begin{tabular}{|c|c|c|}
\hline Variables & Percentage & Mean \\
\hline \multicolumn{3}{|l|}{ Age } \\
\hline$\leq 20$ & 2.5 & \\
\hline $21-30$ & 19.9 & \\
\hline $31-40$ & 15.8 & 48.2 \\
\hline $41-50$ & 20.0 & \\
\hline $51-60$ & 14.1 & \\
\hline $61-70$ & 13.4 & \\
\hline 71 and above & 14.1 & \\
\hline \multicolumn{3}{|l|}{ Sex } \\
\hline Male & 62.5 & \\
\hline Female & 37.5 & \\
\hline \multicolumn{3}{|l|}{ Marital status } \\
\hline Singe & 18.3 & \\
\hline Married & 75.8 & \\
\hline Widowed & 5.8 & \\
\hline \multicolumn{3}{|l|}{ Educational Level } \\
\hline No formal education & 10.0 & \\
\hline Primary school attempted & 13.3 & \\
\hline Primary school completed & 25.8 & \\
\hline Secondary school attempted & 15.8 & \\
\hline Secondary school completed & 26.7 & \\
\hline Tertiary education & 8.5 & \\
\hline \multicolumn{3}{|l|}{ Household size } \\
\hline 1-4 persons & 30.0 & \\
\hline 5-8 persons & 57.5 & \\
\hline 9-12 persons & 11.6 & 6 \\
\hline 13 persons and above & 0.8 & \\
\hline \multicolumn{3}{|l|}{ Major occupation } \\
\hline Farming & 40.8 & \\
\hline Trading & 30.0 & \\
\hline Civil/public service & 11.7 & \\
\hline Artisan & 17.5 & \\
\hline \multicolumn{3}{|l|}{ Monthly income } \\
\hline $1000-20000$ & 57.8 & \\
\hline $20100-40000$ & 39.1 & $28,406.78$ \\
\hline 40100-60000 & 6.8 & \\
\hline$\geq 60100$ & 13.6 & \\
\hline
\end{tabular}

\section{Perceived Causes of Erosion}

Table 2 shows that the majority (99.2\%) of the respondents indicated that rain water run off was the major cause of soil erosion in the area, $98.3 \%$ indicated poor road construction, $96.7 \%$ stated deforestation, while $95.8 \%, 92.5 \%$, and $80.0 \%$ slope of the farm land, soil type, sand mining as major causes of soil erosion. On the other hand 
$66.7 \%$ of the respondents indicated population density, while $60.0 \%$ indicated quarrying of rocks as major causes of erosion in the area. These findings corroborate that of Udegbu Ozulumba, Ejikeme, Okosun, Anierobo, Obi et. al., (2016) who stated that excavation of red earth and sand, construction of road without drainage channels, uncontrolled population growth are major activities that exacerbate soil erosion in Anambra State. This calls for a proper drainage system in the area so as to control the excessive water run-off, good rood construction, and an improved system of farming. Indiscriminate sand mining and quarrying of rock should also be looked into in order to remedy the issue of soil erosion in the area.

Table 2: Farmer's perception on the causes of erosion on their farmland

\begin{tabular}{ll}
\hline Causes of erosion & Percentage \\
\hline Rain water run off & 99.2 \\
Deforestation & 96.7 \\
Soil type & 92.5 \\
Slope of the land & 95.8 \\
Excessive bush burning & 23.3 \\
Population density & 66.7 \\
Poor road construction & 98.3 \\
Sand mining & 80.0 \\
Quarrying of rocks & 60.0 \\
Crops that attracts human & 12.5 \\
traffics & \\
Overgrazing & 20.0 \\
The gods & 10.8 \\
\hline
\end{tabular}

\section{Erosion Control Practices Used by Farmers}

Entries in Table 3 show that all (100\%) the respondents adopted mixed cropping, tie ridging and mulching as control practice against erosion. 99.2\% adopted use of organic manure, land smothering, shifting cultivation and strip terracing, 98.3\% adopted strip cropping, $97.5 \%$ adopted stone terracing, contour terracing and earth dams, $96.7 \%$ adopted construction of diversion ditch while $95.8 \%$ adopted wind breaking as control practice. These soil erosion control techniques no doubt, could be associated with age long traditional soil/land management practices of the farmers in Anambra state.

This scenario underscores the need for soil erosion control activities under the Anambra state ADP to be anchored on the existing land management practices in order to stimulate desirable participation among the farmers This agrees with findings of (Okorafor, Akinbile and Adeyemo, 2017) which advocated the use of simple methods of erosion control such as mulching, bunding, and cover cropping, which are within the capacity of the farmers to establish and maintain, with external support for sound traditional farming practices and more effective but expensive erosion control measure from government and development agencies. 
Table 3: Erosion control practices used by farmers

\begin{tabular}{ll}
\hline $\begin{array}{l}\text { Erosion control practices } \\
\text { adopted by farmers. }\end{array}$ & Percentage \\
\hline Strip cropping & 98.3 \\
Windbreak & 95.8 \\
Use of organic manure & 99.2 \\
Cross strip & 99.2 \\
Stone terracing & 97.5 \\
Contour terracing & 97.5 \\
Mixed cropping & 100.0 \\
Tie ridging & 100.0 \\
Mulching & 100.0 \\
Grade bond & 95.8 \\
Construction of diversion & 96.7 \\
ditch & \\
Land smothering & 99.2 \\
Earth dams & 97.5 \\
Shifting cultivation & 99.2 \\
Strip terracing & 99.2 \\
\hline
\end{tabular}

\section{Challenges to Farmers' Use of Erosion Control Measures}

Table 4 shows the challenges to farmers' use of erosion control practices and they include unavailability of resource required $(\bar{x}=3.44)$, high cost of using the practice $(\bar{x}=3.23)$. The result reveals that unavailability of resources required to control erosion has posed a big challenge to the respondents. Farmers may only have resort to local resource to control erosion which often times are very not effective in controlling erosion. Cost of using the practice is also a big challenge to the farmers in the sense that these farmers hardly have enough income to feed their household not to talk of engaging in meaningful erosion control practices. This would leave the farmers with no option than to resort to cheaper system of erosion control measures which may be inefficient and ineffective too.

Table 4: Challenges to use of erosion control practices

\begin{tabular}{lll}
\hline Challenges & Mean & Std. Deviation \\
\hline $\begin{array}{l}\text { High cost of using the } \\
\text { practice }\end{array}$ & $\mathbf{3 . 2 3}$ & 1.096 \\
$\begin{array}{l}\text { Difficulty in understanding } \\
\text { the practice }\end{array}$ & 2.20 & 0.717 \\
$\begin{array}{l}\text { Difficulty in using the } \\
\text { practice } \\
\text { unavailability of resources } \\
\text { required }\end{array}$ & $\mathbf{3 . 4 4}$ & 0.702 \\
Size of land in involved & 2.18 & 0.951 \\
\hline
\end{tabular}




\section{Attitude of Farmers to Erosion Control}

Results in Table 5 show that respondents indicated the positive statements including: it is good to adopt some erosion practices as it helps to save the soil $(\bar{x}=2.68)$,am interested in issues concerning erosion as this will help me gain knowledge of how to control it $(\bar{x}=2.68)$, I always teach their family members how to control erosion on their farmland/homes $(\bar{x}=2.56)$, I will like to be trained about erosion control even though it has not directly affected them $(\bar{x}=2.55)$. On the other hand, findings reveal that respondents disagreed to the negative attitude statements including: I will not waste my time in any erosion control program $(\bar{x}=0.97)$, erosion control is a tedious work which they will not want to engage in $(\bar{x}=0.96)$, erosion control practices are difficult to understand $(\bar{x}=0.92)$, indicates that they have very small farm land so they are not bordered about erosion control $(\bar{x}=0.68)$, I don't want to engage in erosion control since it does not yield money ( $\bar{x}=0.67)$, I will wait for erosion to happen in my farm land/home before thinking of how to control it ( $\bar{x}=0.63)$, erosion control should be the business/concern of the government not them $(\bar{x}=0.62)$, erosion has never affected them so am not concerned about erosion control ( $\bar{x}=0.47)$, my farm /home are not prone to erosion, am not interested in learning about erosion control practices $(\bar{x}=0.43)$, also indicated that they don't consider using any erosion control practice since they are all costly to use $(x=0.29)$, erosion happens naturally so I don't need to disturb their selves about the control $(\bar{x}=0.19)$. The result shows that farmers have the right attitude to erosion control and are willing to control erosion in their environment. This is a very strong indication that the farmers will participate actively in erosion control projects can programmes. They can also undertake personal erosion control measures. Ogunjinmi and Onya (2016) found that there is a significant positive relationship between attitude and behaviour. 
Table 5: Attitude of farmers to erosion control

\begin{tabular}{|c|c|c|}
\hline Attitude variable & Mean & STD \\
\hline $\begin{array}{l}\text { It is good to adopt some erosion control practices as it helps save the } \\
\text { soil }\end{array}$ & 2.68 & 0.505 \\
\hline $\begin{array}{l}\text { I am interested in issues concerning erosion as this will help me gain } \\
\text { knowledge on how to control it }\end{array}$ & 2.68 & 0.521 \\
\hline $\begin{array}{l}\text { I always teach my family members how to control erosion in our } \\
\text { farmland/home }\end{array}$ & 2.56 & 0.591 \\
\hline $\begin{array}{l}\text { I will like to be trained on erosion control even though it has not } \\
\text { directly affected me }\end{array}$ & 2.55 & 0.672 \\
\hline $\begin{array}{l}\text { It is good to share information about erosion control with friends and } \\
\text { neighbours }\end{array}$ & 2.49 & 0.635 \\
\hline o avoid cutting down trees as this will help reduce erosion & & 0.769 \\
\hline & & 0.753 \\
\hline $\begin{array}{l}\text { I will be free to allow any government /public erosion control practices } \\
\text { that will involve my land }\end{array}$ & 2.20 & 0.751 \\
\hline $\begin{array}{l}\text { I think that minimum or zero tillage should be adopted by farmers to } \\
\text { help stop erosion }\end{array}$ & 1.48 & 0.869 \\
\hline y time on any erosion control programme & 0.97 & 0.859 \\
\hline engage in & 0.96 & 0.691 \\
\hline ficult to understand & 0.92 & 0.705 \\
\hline & 0.68 & 0.568 \\
\hline I don't want to engage in erosion control since it does not yield money & 0.67 & 0.585 \\
\hline $\begin{array}{l}\text { I will only wait for erosion to happen in my farm land/home before } \\
\text { thinking of how to control it }\end{array}$ & 0.63 & 0.581 \\
\hline $\begin{array}{l}\text { Erosion control should be the business/concern of the government not } \\
\text { me }\end{array}$ & 0.62 & 0.745 \\
\hline $\begin{array}{l}\text { Erosion has never affected me so am not in interested in learning } \\
\text { about erosion control }\end{array}$ & 0.47 & 0.549 \\
\hline $\begin{array}{l}\text { My farm/home is not prone to erosion, so am not interested in learning } \\
\text { about erosion control practices }\end{array}$ & 0.43 & 0.529 \\
\hline $\begin{array}{l}\text { I don't consider using any erosion control practices since they are all } \\
\text { costly to use }\end{array}$ & 0.29 & 0.627 \\
\hline $\begin{array}{l}\text { Erosion happens naturally so I don't need to disturb myself about the } \\
\text { control }\end{array}$ & 0.19 & 0.416 \\
\hline
\end{tabular}

\section{Conclusion and Recommendations}

Farmers in the area have adopted a number of erosion control, measures. Cost of using some erosion control practices, difficulty in using some of the practices, and difficulty in understanding the practice were some of the challenges farmers encountered in using erosion control practices in the area. However, respondents had the right attitude to erosion control and therefore could be said to have a good disposition to erosion control in the area. It is recommended that extension should help famers by teaching them some erosion control practices in order to make easy for them to know them and learn the skills on how to use them. Also, government at all levels should provide financial incentives to farmers so that they can afford some good erosion control practices which are costly for them. On the order hand, government should embark on erosion control projects in order to reduce the 
Creative commons User License: CC BY-NC-ND

Abstracted by: EBSCOhost, Electronic Journals Service (EJS),

Google Scholar, Journal Seek, Scientific Commons,

Food and Agricultural Organization (FAO), CABI and Scopus
Journal of Agricultural Extension

Vol. 22 (3) October, 2018

ISSN(e): 24086851; ISSN(Print); 1119944X

http://journal.aesonnigeria.org

http://www.aiol.info/index.phpliae

Email: editorinchief@aesonnigeria.org

challenges farmers are facing while trying to control erosion on their farmlands and homes.

\section{References}

Akinbile, L .A, Aminu, O.O, Kolade, R.I, (2018) Perceived Effects of Climate Change on Forest Dependent Livelihoods in Oyo State, Nigeria. Journal of Agricultural Extension. Vol 22(2) pp 169(2)179

Babalola, D. A., and Olayemi, J. K.,(2013). Determinants of Farmers' Preference for Sustainable Land Management Practices for Maize and Cassava Production in Ogun State, Nigeria. Invited paper presented at the 4th International Conference of the African Association of Agricultural Economists, September 22-25, 2013, Hammamet, Tunisia

Chapagain, T and Manish N.R.,(2017) Agronomic Challenges and Opportunities for Smallholder Terrace Agriculture in Developing Countries. Journal of Plant Science .vol 8:331

Dessie, E.,(2013) The Sustainable Livelihoods Approach as a Transformation tool for the Western Sahara Conflict. Https://www.Irenees. Net/bdf-fiche-analyse1023-en.html,

Food Agriculture and Organization (FAO),(2016) Sustainable Land Management .Https:// www. Fao. Org/ desertification. Accessed on 27/5/2018

Nwaobiala, C. U.(2018) Farmers' adoption of cassava agronomic practices and intercrop technologies in Abia State, Nigeria. Journal of Agricultural Extension, 22 (2): 82-96.

Obi, N. I. and Okekeogbu C. J., (2017) Erosion problems and their impacts in Anambra State of Nigeria: A case of Nanka Community. International Journal of Environmental and Pollution Research, 5 (1) 24-37.

Obiadi, I. I., Nwosu C. M., Ajaegwu, N. E., Onuigbo, N. E., (2012), Gully erosion in Anambra state South East Nigeria: Issues and solution. International Journal of environmental science volume 2, no2

Ogunjinmi, A.A and Oniya B.J.,(2016). Determinant of Environmental Attitudes and Behaviours of Nigeria undergraduates; A case of Federal University of Technology, Akure, Nigeria, Applied Tropical Agriculture 21(1):175-182.

Okorafor, O. O Akinbile, C. O and Adeyemo, J.,(2017) Soil Erosion in South Eastern Nigeria. Scientific Research Journal (Scirj), Volume 5, (9) pp 30-37

Onu, D. O. (2013) Farm Level Analysis of Investment Behaviours in Soil Conservation and Erosion Control Practices in the Ecologically Vulnerable Communities in Southeast, Nigeria. Agriculture and Biology Journal of North America 4 (4): 441-58.

Onyenekwe, R.U.,(2016) Effects of Livelihood Strategies on Sustainable Land Management Practices among Arable Crop Farmers in Imo State, Nigeria. Nigeria Journal of Agriculture, Food and Environment. Vol 12(3):230-235.

Pidiwirmy M, (2010) Carbon cycle, in Encyclopedia of earth, Cleveland, C. J.E.d. Environmental information coalition, National council for science and the Environmental, Washington D. C. First published in the Encyclopedia of earth, may 31, 2010, Retrieved on 11 August 2018.at http;//www.eoearth.org/article/ carbon cycle. 
Poufoun J. N. (2016). Livelihood strategies, deforestation and biodiversity conservation: a microeconomic analysis using rural household survey in the Tridom tranboundary conservation landscape. A PhD thesis submitted to the Department of Economies and finances, Université de Lorraine.

Raufu, M.O. and Adetunji, M.O. (2012), Determinant of Land Management Practices among Crop Farmers in South-Western Nigeria. Global Journal of Science Frontier Research Agriculture \& Biology Volume 12 Issue 1 Version 1.0 January 2012.

Saheed, M and Isa, E., (2017).The Challenges of Food Security in Nigeria. Journal of Biomedical and Life Sciences. Vol 4. No 12

Saleh, J. M, Man, N., Lafta, A.H, Saleh, M. J, Hassan, S, Nawi , N. M and Kshash, B. H., ( 2016) A Review: Training Requirement of Agriculture Extension Officers in Iraq. Asian Journal of Applied Sciences, vol 9:34.DOI: 10.3923/ajaps.2016.34.40.

Udegbu S. N., Ozulumba C., Ejikeme K., Okosun A., Anierobo C., Obi N. I., Emeasoba U. R. B., Agwuna K. K. and Iroegbu A. (2016). Soil erosion in Awka, Anambra State (Nigeria): Assessing the social and environmental effect. Accessed from: Https://www.Researchgate.Net/Publication/310793386 -Soil -Erosion -In Awka-Anambra -State -Nigeria -Assessing -The -Socia and Environmental Effects On 6th August, 2018.

Udimal T. B. Jincai Z., Mensah O. S. Caesar A. E.(2017) Factors Influencing the Agricultural Technology Adoption: TheCase of Improved Rice Varieties (Nerica) in the Northern Region, Ghana. Journal of Economics and Sustainable Development, 8 (8):137-148

Ume, N.C, Enwereuzor, A.I., Egbe, C.A, Ike, M.C and Umo S.J., (2014) Application of Geographic information system and remote sensing in identifying the impacts of gully eroding in Urualla, Ideato North Local Government area, Imo state. Nigeria Global Research Journal of Science 3(3):1-8

United Nations, (2014) Indicators for Sustainable Development goals. New York: United Nations.

Yang. L, Liu, M, Lun, F., Min. Q., Zhang. C and Li, H., (2018) Livelihood Assets and Strategies among Rural Households: Comparative Analysis of Rice and Dryland Terrace Systems in China. Journal of Sustainability Vol 10, 2525; DOI: 103390/su10072525. 